\title{
anemon
}

Muş Alparslan Üniversitesi Sosyal Bilimler Dergisi

Journal of Social Sciences of Muş Alparslan University

Yı//Year: 2017 • Cilt/Volume: 5 • Sayı/Number: 1

ISSN: 2147-7655 • e-ISSN: 2149-4622

ÖZGÜN ARASSTIRMA • ORIGINAL ARTICLE

\section{Şiddet ve Erkeklikler: Av Mevsimi ve Gönül Yarası Filmleri Üzerinden Türkiye'deki Erkeklik Biçimlerine Bakmak}

\author{
Burcu ŞENTÜRK 1, a \\ ${ }^{1}$ Arş. Gör. Dr., Ege Üniversitesi, İktisadi ve İdari Bilimler Fakültesi, İşletme Bölümü- İzmir / Türkiye \\ Başvuru tarihi: 15 Ağustos 2016 \\ Düzeltme tarihi: 19 Kasım 2016 \\ Kabul tarihi: 6 Aralık 2016
}

Öz

Popüler Türk sinemasında önemli bir yeri olan Yavuz Turgul'un yönetmenliğini ve/veya senaristliğini üstlendiği filmlerin temel ekseni makro düzeyde gerçekleşen kırdan kente göç gibi toplumsal değişimlerle farklılaşan toplumsal yapı ve kaybolan değerlerin bireylerde yarattığı çelişkiye dayanmaktadır. Yönetmen özellikle 90'lı ve sonrasındaki yıllarda çektiği filmlerle bu toplumsal değişimlerdeki erkeklik, erkekler arası dayanışma ve erkeklerin şiddeti gibi temaları kurgusal zenginlikle izleyiciye sunmaktadır. Bu filmlerde sevilen, arzu nesnesi kadın, erkek ve silah üçlüsü bir arada seyredilir. Bununla birlikte Turgul sinemasında hikâyenin iki erkek arasındaki çatışmalı ama bir o kadar da yakın dostluktan beslendiğini görmek mümkündür. Senarist/yönetmenin anlattığı erkeklerin, erkek dostluğunun hikayesidir aslında. Bu çalışma Yavuz Turgul'un 2000 sonrası yönetmenliğini üstlendiği Gönül Yarası ve Av Mevsimi isimli filmlerindeki erkek karakterlere odaklanmaktadır. Filmlerdeki erkek karakterler eşliğinde Türkiye'deki cinsiyet rejimindeki erkekliklerin çeşitli görünümleri tartış1lacaktır. Erkekliğin çoğulluğuna dikkat çeken bu çalışma erkeklik biçimlerinin temel belirleyeninin şiddetle olan bağlantı olduğunu öne sürmekte ve bu biçimlerin sinemadaki izdüşümleri üzerine bir eleştirel inceleme sunmaktadır.

\section{Anahtar Kelimeler}

Toplumsal Cinsiyet, Erkeklik, Şiddet, Yavuz Turgul, Türk Sineması

\footnotetext{
a Sorumlu Yazar/Correspoding Author: Ege Üniversitesi, İktisadi ve İdari Bilimler Fakültesi, İşletme Bölümü, 35100, Bornova / İzmir / Türkiye

e-posta: burcusentrk@gmail.com 


\title{
Violence and Masculinities: Looking at Masculinity Forms in Turkey Through Hunting Time and Lovelorn Films
}

\begin{abstract}
Movies directed and/or written by Yavuz Turgul who has a particular position in Turkish cinema basically focus on the effect of changing social structure and the effect of disappearance of social values on the individuals. The director presents themes such as masculinity, solidarity among men and violence with these social changes with a fictive substance to the audience in his films directed since the 1990s. In these movies, trilogy of loved woman who is an object of desire is seen together with men and guns. Additionally, it is possible to see that in Turgul's cinema the story is supported by a conflicting relation and also a close friendship between men. Indeed, what author-director tells is a story of men and male friendship. This study focuses on Hunting Time and Lovelorn, directed by Turgul after 2000. Various view of masculinities in gender regime in Turkey will be discussed through the male characters of these films. Drawing attention to the plurality of masculinity, this study suggests that main determinant of masculinity types is their connection with violence and the study presents a critical analysis about the reflection of these types to the cinema.
\end{abstract}

\section{Keywords}

Gender, Masculinity, Violence, Yavuz Turgul, Turkish Cinema

\section{GÍRIŞ}

Filmler estetik kaygıların ve belirleyicilerin yanı sıra, ortaya çıktıkları dönemin koşullarından fazlasıyla etkilenir, içinde bulundukları dönemin koşullarını ve toplumsal olguların algılanma biçimlerini yansıtırlar. Öte yandan, film yaratıcılarının zihninde bilinçli ya da bilinçsiz olarak ulaşmak istedikleri kitleye dair bir fikir vardır ve filmler aslında dönemin izleyici kitlesi hakkında da birer bilgi kaynağıdır. Sinema eserlerinden yola çıkarak genellemelere imkân verecek bilginin üretilmesi pek mümkün değildir, ancak diğer anlatılar gibi sinemanın da çekildiği döneme dair bir gerçeklik kesiti, kurgusu ya da gerçeklik yorumu sunduğu aşikardır. Bununla birlikte gerçeklikle özel bağlarından ötürü özellikle popüler filmlerde, gerçekmiş gibiliğin inşası, inandırıcılığın ve özdeşlemenin yaratılması açısından büyük önem taşımaktadır (Abisel 2005:295). Aynı zamanda sinema kadınlar ve dişillik ve erkekler ve erillik, kısacası cinsel farklılıklar üzerine mitlerin üretildiği, bunların temsil edildiği kültürel bir pratiktir (Smelik, 2006:1). $\mathrm{Bu}$ açıdan düşünüldüğünde sinema eserleri toplumdaki erkeklik ve kadınlıkların belirlendiği toplumsal cinsiyet rejimi ve rollerinin algılanma ve yeniden üretilme biçimleri hakkında derinlikli bilgi içerirler.

Erkeklik çoğu şeyi kuşatan bir sosyal söylem aracılığıyla imal edilir (Sterling 1995, akt. Özarslan 2016). Medya ve popüler sanat ürünleri de bu araçlar arasında yer alır. Bu 
çalışmada da Türkiye'deki erkeklik biçimleri Türkiye'de popüler sinemada önemli bir yönetmen olan Yavuz Turgul'un iki filmi Gönül Yarası ve Av Mevsimi üzerinden okunmaya çalışılacaktır. Çalışmada öncelikle okuyucuyu ana tartışmaya hazırlayabilmek adına Yavuz Turgul sineması tanıtılacak, böyle bir çalışma için neden Yavuz Turgul sinemasından iki örnek film seçildiği anlatılacaktır. Akabinde ise filmler üzerinden incelenecek olan erkekliğe dair kavramsal bir tartışma yapılacak ve seçilen filmler eşliğinde Türkiye'deki erkeklik biçimleri analiz edilecektir. Bu erkeklik biçimlerini belirleyen temel öğenin şiddet olduğu öne sürülecek ve bu makale kapsamında şiddetle sevenler, idealist eksik babalar ve beyaz erkekler olarak adlandırılacak erkeklik tiplerinden bahsedilecektir. İlerleyen sayfalarda tartışılacağı üzerine erkekliğin tahakküm ilişkileri ile olan organik bağından ötürü böyle bir analiz şiddet kavramının ana unsur olarak tartışmaya katılmasını gerektirmiştir. Bu doğrultuda erkeklik biçimleri özellikle şiddetle kurdukları bağ üzerinden anlaşılmaya çalışılacaktır. Şiddet, kadına karşı şiddet ve hane içi şiddet ilk günlerinden itibaren Türk sinemasında değişen şekillerde yer almıştır. Filmlerde temel olarak üç şekil erkek şiddeti görmek mümkündür: birincisinde erkek çok sinirlenir, kendine hâkim olamaz ve şiddete başvurmak zorunda kalır, ikincisinde kadın karakter cezalandırmanın bir parçası olarak bu şiddeti hak eder, üçüncüsünde ise şiddet hali hazırda erkek kimliğinin ayrılmaz bir parçasıdır (Abisel 2000).

\section{YAVUZ TURGUL SINEMASI VE ERKEKLİK}

1970’li yıllardan bu yana yer aldığı Türk sinemasında az sayıda filmiyle Türk sinemasını derinden etkileyen yönetmenlerden birisi Yavuz Turgul'dur. Turgul'u Türk sineması için önemli yönetmenlerden biri haline getiren Eşkıya filmi ile yakaladığı başarıdır. Bu filminde Turgul, 1960'ların Yeşilçam filmleri ile popüler Hollywood sineması arasında bir metinler arasılık kurgulamış, ticari olarak ilgi çeken öğeleri (aksiyon, melodrama, romantizm, film yıldızları ve teknik üstünlük) Avrupa ülkeleri ile ortak yapımın neticesinde Batı'nın standartlarında güçlü senaryo, profesyonel oyunculuk, yönetmenlik ve teknik mükemmeliyet ile birleştirmiştir (Dönmez- Colin, 2013: 36). Eşkıya'nın elde ettiği başarı, 90'ların ortasından sonra canlanan Türk sinemasının popüler kanadına yön vermiş ve yeni popüler sinemanın sürekli başvuracağ bir formül sunmuştur (Suner, 2005: 34). Aslında Turgul, bu film ile Türk sinemasında yeni bir dönem başlatmış ve bu filmde sunduğu formülden hem diğer yönetmenler hem kendisi kullanılmıştır.

Şener Şen, Yavuz Turgul'a benzer bir şekilde, uzun sinema kariyeri boyunca nispeten az filmde yer almıştır. Şen'i diğer pek çok sinema yıldızından ayıran, yıllar önce çekilmiş filmlerinin repliklerini hala hatırlanır kılan şey ise çok az kişinin başarabildiği "komik"ten "komedyen"e geçişi başarıyla gerçekleştirebilmesi; bu sayede dram, komedidram ve trajik komedi oynamaya yatkın ve hazır olmasıdır (Scognamillo, 2005: 11). Bu zorlu geçiş ile birlikte, Şekerpare'nin Ziver Bey'i, Banker Bilo, Hababam Sınıfı'nın Badi Ekrem'i ve benzeri karakterler komediyle birlikte kötünün içindeki sevilecek yanları izleyiciye taşımıştır. Daha da ötesinde bu güldürü karakterleri Züğürt Ağa, Eşkıya' daki Baran, Gönül Yarası' ndaki Nazım Öğretmen'in trajik karakterler olarak kurgulanmasını zorlaştırmamıştır (Scognamillo, 2005). Sinema oyunculuğunda daha kolay yol olarak bilinen kısa ve hareketli karikatür rollerle sinema kariyerine başlayan Şener Şen seçici bir 
devamlılık sergilemiş ve kariyerinin ikinci evresinde komedyen kimliği unutulmadan farklı rollerde görünmüştür. Alin Taşçıyan, Yavuz Turgul üzerine kaleme aldığı bir yazıda Şener Şen'e de değinir ve şöyle der: "Şener Şen'in kariyerinin ilk döneminde güldürü filmlerinin ustası Ertem Eğilmez, Şen’in sanat gücünü ortaya çıkartmış ancak kendine has karakterler yaratmasına imkân vererek onu bir yıldız yapan Yavuz Turgul'dur'. Turgul ile Şen'in bağını kuran ve bu ikilinin ilişkisinin potansiyelini ortaya çıkartan film ise, Turgul'un senaryosunu yazdığg 1986 yapım Züğürt Ağa'dır (Taşçıyan, 2011: 200). Ancak bu tek taraflı bir değer katma durumu değildir. Türk sinemasının bu iki özgün sanatçısının birlikteliği iki taraflı bir beslenmenin var olduğu bir ilişkidir zira Scognamillo'nun da dediği gibi (2005: 114) "Yavuz Turgul, Şener Şen'i ve yeteneklerini ne kadar iyi biliyorsa, Şener Şen de Turgul'un yazdığı karakterlerin kendisine neler getirdiğini çok iyi bilir. Bir yerden sonra bir reçeteden söz edebiliyorsak bu reçete her iki filmde, her iki taraf için de işe yarar olmuştur”".

Yavuz Turgul'un yönetmenliğini ve/veya senaristliğini üstlendiği filmleri ele aldığımızda bu kurguların en temelde makro düzeyde gerçekleşen kırdan kente göç gibi toplumsal değişimlerle farklılaşan toplumsal yapı ve kaybolan değerlerin bireyler üzerindeki etkisini görselleştirdiği söylenebilir. Örneğin Turgul'un senaryosunu yazdığı Zügürt Ağa'nın kente indiğinde çizmelerini çıkartarak çiğköfte satması; Türk sinemasında yeni bir dönem başlatan ve Turgul'un yönettiği Eşkıya'nın ana karakteri Baran'ın plaza koridorlarında Keje'yi takip etmesiyle Turgul büyük toplumsal değişimlerin birey düzeyinde fotoğraflarını çekmektedir. Bununla birlikte Turgul'un en önemli katkısı karakterlere toplumsal gerçekçi bir perspektifle yaklaşması, suç fillmleri türünün yerel motiflerle bezendiği bir yapı içinde suçun sosyolojik derinliklerine inmesidir. Kurbanı da toplumsal gerçekçi bir yaklaşımla tanımlar ve gelenek kavramını sebep-sonuç ilişkisi içinde yerel bir aktör olarak konumlandırır (Dönmez- Colin 2013).

Turgul, 90’lı ve sonrasındaki yıllarda çektiği filmlerle bu toplumsal değişimlerdeki erkeklik, erkekler arası dayanışma ve şiddet gibi temaları kurgusal zenginlikle izleyiciye sunmaktadır. Eşkıya (1996), Gönül Yarası (2005), Kabadayı (2007) ve Av Mevsimi (2010) filmlerinde sevilen, arzu nesnesi kadın, erkek yoldaşlığı-rekabeti, susturulan kadın, erkeklerin şiddetini hep bir arada seyrederiz. Bu üçlü içindeki tek kahraman erkektir. Turgul, filmlerinde elbette kadın karakterler de yer alır ancak kadınlar hiçbir zaman kahraman değillerdir. Temel bir unsur olarak kadınsızlık hemen dikkati çeker Turgul sinemasında. Kadın imgesi, işlevsel olduğu ölçüde yer bulur. Kadın, erkeklerin yanında ikincil plandadır ve erkeklerin hikayesinde, ana temaya temas ettiği ölçüde kendine yer bulur

Bununla birlikte Turgul'un senaryosunu yazdığı ve/veya yönettiği filmlerde hikâyenin iki erkek arasındaki çatışmalı ama bir o kadar da yakın dostluktan beslendiğini görmek mümkündür. Eşkıya, Muhsin Bey, Gölge Oyunu, Gönül Yarası, Av Mevsimi filmlerinin hepsinde erkek dostluğunu ve rekabeti görmek mümkündür. Erkek dostluğu, Turgul'un filmlerinin sosyolojik bir okumasını olanaklı kılan üç ana temadan bir tanesidir (Yüksel, 2013: 285). ${ }^{1}$

Kısaca söyleyecek olursak Eşkıya'da Baran ve Berfo'nun eskiye dayanan dostluğu ikisinin de Keje'ye olan aşkları neticesinde bitmiş, yıllar içinde bir düşmanlığa dönmüştür. Öte taraftan Baran'ın Keje'yi bulmak için İstanbul'a gelmesiyle tanıştı̆̆ 
Cumali ile de aralarında bir dostluk kurulmuş, film boyunca bu iki erkek hep birlikte hareket etmişlerdir. Eşkıya her şeyi kurtarma ve feda etmeye indirerek Yeşilçam'da var olan para-aşk, aşk-babalık sorumluluğu, adanma-bireysel özgürlük meselelerine değinmiş (Erdoğan 2002: 234), ve bu ikilikleri erkek dostluğu-rekabeti eşliğinde anlatmıştır.

Muhsin Bey ise Urfa'dan İstanbul'a şarkıcı olmak için gelen Ali Nazik ile organizatörlük yapan Muhsin Bey’in yollarının kesişmesini konu eder. Muhsin Bey, Ali Nazik’i koruyup kollar; lakin yeni ve eski, değişim ile gelenek arasındaki çatışma arabesk müzik ve sanat müziği ile sembolleşir ve Muhsin Bey ve Ali Nazik arasında gizlice yürüyen bir rekabeti mümkün kılar. Filmin sonunda kazanan eskinin karşısında yeni ve değişim; Muhsin Bey'in karşısında ise Ali Nazik olur. Gölge Oyunu (1992) ise filmin afişinin de belli ettiği üzere iki erkeğin dostluğu üzerine kuruludur. Turgul'un en güçlü senaryolarından biri olan ve dönemine göre 1şı kullanımı anlamında büyük övgüler alan bu filmin ana karakterleri pavyonlarda ayaküstü komedyenlik yapan Abidin ve Mahmut'tur. Kadınlarla kurdukları ilişki biçimi bu iki karakteri tezat kılar; eskiden gemicilik yapan Abidin kadınlara çok düşkündür bir yetimhanede büyümüş olan Mahmut ise karşı cinse olan utangaç tutumu ve hassas yapısıyla yoldaşından ayrılır. Çok iyi anlaşan ve ayrışan; çatışan ama dostluklarını sürdüren bu ikilinin hayatına konuşamayan bir kadının girmesi dostluklarını ve çatışmalarını daha belirgin kılacaktır.

İlerleyen sayfalarda daha ayrıntılı tartışılacağı üzere Gönül Yarası'nda erkek çatışması bir "erkeklik" çatışmasıdır; zira aynı kadına sevgi duyan iki farklı erkeğin erkekliği çarpışmaktadır. Av Mevsimi’nde ise senarist/yönetmenin bir cinayet vakası çerçevesinde anlattı̆̆ı; erkeklerin, erkek dostluğunun hikayesidir aslında. Turgul ve Şener ikilisinin son filmi olan Av Mevsimi erkekler dünyasındaki rekabeti bir av olarak kurgulayarak iki erkeğin avcılık yarışı içinde erkekliğin çeşitli biçimlerinin çatışmalarını ve dostluklarını anlatmaktadır.

\section{ERKEKLIIKLERİ TANIMLAMAK}

Erkeklik çalışmaları, 1970'li yıllarda feministlerin meseleye eğilmesiyle başlamış, 1980’lere doğru yükselişe geçen ve disiplinler arası bir alan olarak kurulan erkeklik incelemeleri ağırlıklı olarak profeminist bir alan olarak şekillenmiştir (Bozok 2011: 43). İlerleyen yıllarda ise queer çalışmalardan savaş karşıtlarına kadar pek çok çevre bu alana katkıda bulunmuştur (Özarslan 2016:71).

Erkekliğin kendisi cinsiyetlendirilmiş toplumsal ilişkilerin bir ürünüdür ve her an yeniden oluşmaktadır (Kimmel ve Messner, 2001). Erkeklik belirli normlara sahip bir kurgudur ancak güncel olarak stabil, tarihsel olarak verili, cinsel olarak sabit bir cinsiyet olmaktan ziyade dönemsel olarak söylemleri ve kurgusu değişen, uluslar ve ulusların alt bölgelerine göre yeni anlamlar edinen, tarihsel ve doğal olarak ön belirlenemeyen bir kimlik biçimidir (Özarslan 2016:73). Toplumsal Cinsiyet de tıpkı tüm toplumsal değerler, kurallar ya da genel yapıntılar gibi, toplumsallaşma yoluyla yeniden üretilir ve kuşaktan kuşağa aktarılır. Toplumsallaşma belli başlı fikirlere, duygulanımlara ilişkin davranış kalıplarının oluşması, bir anlamda birey ile çevresinin işbirliğinin bir sonucudur. Ancak sanılanın aksine toplumsal cinsiyet ne sadece kadın ve erkek ikiliğiyle sınırlıdır ne de biyolojik 
cinsiyetler ve ikiliklerle birebir örtüşme gereğindedir; çokludur ve inşa edilir (Butler 2008). Toplumsal cinsiyet gibi erkeklik de çokludur, inşa edilir ve sınırları biyolojik sınırların çok ötesine uzanır. İlk olarak erkekliğin anlamı kültürden kültüre değişebilir. Kültürel değerler ve geleneksel roller, toplumların cinsiyetleri, kadınlığı ve erkekliği anlama biçimlerini temelden etkiler. Hiçbir coğrafyadaki erkeklik sabit kalmaz, zaman içinde dönüşüme uğrar. Erkeklik tanımı bir kişinin hayatı boyunca da değişikliğe uğrar. Her toplumda aynı anda farklı erkeklik biçimleri ve tanımları birlikte bulunur. Tüm bunlar birlikte düşünüldüğünde sınıf, ırk, yaş, cinsellik, yaşanılan bölge, zaman ve etnisite cinsiyet rollerini dolayısıyla erkekliği belirleyen dinamikler arasındadır. Erkekliğin kendisi cinsiyetlendirilmiş toplumsal ilişkilerin bir ürünüdür ve her an yeniden oluşmaktadır. Farklı erkeklikleri ortak paydada toplayan şey ise kadınlar üzerinde sağlanan iktidardır ve bu iktidardan sağladıkları çıkardır. (Kimmel 2004, Connell 1987, Kimmel ve Messner 2001, Özbay 2013)

Tam da bu noktada erkeklikten değil, erkekliklerden bahsetmek mümkün olmuştur. Tek bir tip erkeklik yoktur, erkeklik çoğul olarak kurulur ve her cinsiyet rejimindeki erkeklikler birbirlerine hiyerarşiktirler. Kavramın işaret ettiği bu çoğulluk ve erkeklik tipleri arasındaki hiyerarşi Connell'ın hegemonik erkeklik kavramının tartışılmasını da zorunlu kılmaktadır. Hegemonik erkeklik, bir erkeklik imajı olarak egemenlik altına alınan kadınlık ve kendisi dışındaki diğer erkeklik biçimleriyle ilişkili olarak idealize edilir (Barrett 2005: 179). Bir kavram olarak hegemonya, her ne kadar farklı bağlamlarda ya da anlamlarda kullanılsa da temel olarak belirli bir toplumsal grubun, sinıfin, milletin ya da devletin diğer toplumsal gruplar, sınıflar, milletler ve devletler üzerinde kurduğu egemenliğe denk düşmektedir. Bu egemenlik yalnızca siyasi ve iktisadi kontrolü değil, aynı zamanda egemen olan kesimin (sınıfın, devletin, grubun vs.) kendi dünya görüşünü diğerlerine de "doğal olan", "normal olan" şeklinde kabul ettirme kapasitesini içermektedir (Chandler, 2009). Temel olarak hegemonya kavramı birtakım değerlerin, çıkarların ve normların geniş kesimlerin rızasını almasına dayanmaktadır. Bu açıdan değerlendirildiğinde tanımı gereği idealize edilmiş erkeklik biçiminin sürdürülmesi için söz konusu kategoriden dişlanan erkeklerin de hegemonik erkekliği desteklemeye gönüllü olması gerekmektedir (Connell, 1987: 178). Nitekim her erkek hegemonik erkekliğin özelliklerine sahip olamamakta ancak içinde yaşadıkları toplumsal formasyon ve cinsiyet rejiminin getirdiği eşitsizliklerle ve tabakalaşma ile birlikte belirli bir tip erkekliğin hegemonik olmasına rıza göstermektedirler. Böylece bütün erkekler bir çeşit hegemonyayla, aralarındaki ilişkinin derecesine göre konum almaktadırlar. Bu çeşitlilik ve çoğulluğa rağmen erkeklik mefhumunun ortak kurucusu kadınların baskılanması ve değişik şekillerde hiyerarşinin farklı basamaklarındaki erkekliklere bağımlı kılınmasıdır.

Medyada Hegemonik Erkek(lik) ve Temsil başlıklı eserde erkekliğin medyadaki temsili üzerine yapılmış farklı çalışmalar hegemonik erkekliğin Türkiye'deki görünümünü "milliyetçi-muhafazakâr, duygularını ifade etmekten kaçınan, saldırganlığı, şiddeti ve gücü yücelten, hiyerarşik ilişkilere dayanan, erkeklerin sahip olduğu ayrıcalıkları görmezden gelen bir tip" olarak vücut bulduğu anlatılmaktadır (Erdoğan 2011). Erkeklerle yüz yüze mülakatlara dayanan bir çalışma ise, katılımcıların şiddeti benimsemeseler bile toplumda bu erkek özelliklerinin kabul gördüğünü anlatmaktadır (Şimşek ve Öner, 2015). Özbay (2013) ise, bir "Türk erkekliği”" ya da "Türkiye'de hegemonik erkeklik” şeması çizmenin mümkün olmadığını ortaya koymaktadır. Ancak 
günümüz Türkiye'sinde hegemonik olan ya da olmayan erkekliklerin paylaştıkları ve paylaşmadıkları özelliklerin ortaya koymaya çalışlabileceğini söylemektedir (Özbay,2013:.188) ve bu özelliklerin askerlik, beden, yaş, mekân, sınıf, popüler kültür, din ve mezhep, siyaset, spor başlıkları ile incelenebileceğini göstermektedir. Türkiye'deki çeşitliliğin özetlenerek hegemonik erkeklik tanımına ulaşılması zordur ve Özbay'ın ifade ettiği gibi bir karikatüre indirilme tehlikesi vardır; lakin bu farklı yaklaşımlar hegemonik erkekliğin toplumsal cinsiyet alanı gibi iktidar ilişkilerinden bağımsız olmadığını, tahakküm ve onun uzantısı şiddetin çeşitli şekilleriyle bağlantılı olduğunu ortaya koymaktadır.

Türkiye'de hegemonik erkekliğin sınırlarını çizmenin ve “Türk erkeği” tanımına ulaşmanın imkansızlığı Türkiye'deki erkek tiplerini analiz edebilmeyi, iktidar ve şiddet kullanımı ile olan bağlarını ortaya koymaya engel teşkil etmemektedir. Bu doğrultuda, yapılan erkeklik tartışması ışığında bir sonraki bölümde Av Mevsimi ve Gönül Yarası filmlerindeki erkek tipleri analiz edilecektir, ancak öncesinde filmler okuyucuya tanitlacaktır.

\subsection{Av Mevsimi}

\subsubsection{Film Özeti}

Film, genç bir kızın konuşması ve kesilen bir kolun ormanlık bir alandaki ürkütücü görüntüsüyle başlar ve genç kızın kurban gittiği cinayetin, cinayet masası tarafindan çözülme sürecini konu alır. Cinayet masasından Ferman, İdris ve Ferman'ın ekibe yeni kattığı Hasan; vücudu parçalanmış Pamuk'un cinayetinin peşine düşerler. Bu cinayet onlara kü̧̈ük uyuşturucu satıcısı Asit, çok zengin bir iş adamı olan Battal Çolakzade, Pamuk'un anne babası ve abileri Abbas ve Vakkas başta olmak üzere pek çok insanla karşı karşıya gelmelerini sağlar. Bir cinayet hikayesi etrafında yan öyküler ile film akar fakat cinayetin çözümü dışındaki yan hikayelerin ve karakterlerin gücü izleyiciyi cinayeti kim işledi sorusundan uzaklaştırır. Çözmeye çalıştıkları cinayet, bu üç polisin hayatını geri dönülemeyecek bir şekilde değiştirir. Av Mevsimi, adına yaraşır biçimde bir av öyküsüdür aslında ancak bu öyküde tek bir av ve avcı yoktur; dahası kimin av kimin avcı olduğu ile avın kuralları da çok belirgin değildir.

Pamuk, ülkenin zengin ve tanınmış iş adamı Battal Çolakzade'nin ikinci eşidir. Bu evlilik ilk bakışta zengin ve yaşlı bir erkeğin gücünü kullanarak genç bir kadınla evlenmesi olarak görülmektedir. Ancak Battal'ın ilk eşi Hilal'in de hala hayatta olması ve aynı evde yaşamaya devam etmesi şüphe uyandırmaktadır. Öte yandan, Battal Çolakzade'nin soruşturmaya dahil edilmesi Ferman ve ekibinin işlerini zorlaştırır. Çünkü Battal devlet içindeki bağlantılarını kullanarak Ferman ve ekibini köşeye sıkıştırmaktadır. Pamuk'un öldürülmesi de ilk başta namus cinayeti olarak görülmeye yatkındır ancak olayların çözümü Karadenizli İdris'in karısıyla arasını düzelttiğini düşünürken aslında onu tamamen kaybettiğini anlamasıyla her şeyi göze alabilecek duruma gelip gizlice Battal'ın ofisine girmesiyle başlar. İdris gerçeği burada Battal'dan öğrenir lakin Battal'ın korumaları tarafından vurulduğu için söyleyemez. Son nefesinde bakış açılarını değiştirmeleri gerektiği anlamına gelen bir işaret yaparak cinayet masası ekibine cinayeti çözmelerinde önemli bir ipucu verir. Olayın namus cinayeti meselesinin çok ötesine 
uzandığını anlayan Ferman; Battal'ı sıkıştırır, Pamuk'un ailesini gözlemler ve Battal ile Pamuk'un evliliğinin göstermelik olduğu anlaşılır. Battal'ın hasta kızı Ceylan için organ nakli gerekmektedir ve Pamuk'un organları bu nakil için uygundur. Battal tüm çalışanlarının kan ve ilik örneklerini almış ve tek eşleşme Pamuk ile olmuştur. Battal Pamuk'un ailesi üzerinde etkilidir ve özellikle bu ailenin kendine ekonomik bağlılığından faydalanarak, Pamuk'un rızası dışında aile ile para vererek anlaşılır ve evlilik gerçekleşir. Organ nakli sonrası Pamuk öldürülür ve parçalanan cesedi muhtelif yerlere dağıtılır. Ancak Pamuk'un Ceylan'a nakledilen organı iflas etmiş ve Ceylan'ın iyileşmesine yaramamıştır. Olay örgüsünü çözen, ufak ayrıntılarla kanıtları da toplayan Ferman, Battal ile konuşmaya gider. İki “avcı” filmin adına yaraşır biçimde son kez ormanlık bir alanda bir araya gelirler. Battal ava çıkmış ancak Ferman'ın kendisiyle konuşmaya gelmesi üzerine kendisi bir ava dönüşmüştür. Ferman, Battal'a Ceylan'ın bu olayı hiç öğrenmeden ölmesi şansını sunar zira filmin başından beri ara ara hatırlattığı üzere Ferman için bir avcının gücü avına duyduğu merhametten gelir. Filmin sonunda bir avcıya dönüşen Ferman'ın avına gösterdiği merhamet sayesinde, Pamuk'un cinayetinin arkasındaki bu olayları kimse öğrenmez ve Çolakzade intihar eder. Av mevsimi başladığı yerde sona ermiş olur.

\subsubsection{Filmdeki Karakterler}

Ferman (Şener Şen): Cinayet masası komiserlerinden Ferman, tecrübesi ve cinayetleri çözerken yaptığı takiplerle teşkilat tarafından "Avcı" olarak adlandırılır. Çoğu arkadaşı bir emekli olmuş, kendisi de artık kariyerinin son demlerindedir. Ferman sakin ve ölçülüdür; birlikte çalıştığı ekip arkadaşları başta olmak üzere iletişim kurduğu toplumsal çevreyi iyi gözlemler; çevresindekilerin dile getirmediklerini rahatlıkla kavrar. Ekibinde yer alanlara tecrübelerini aktarması, yol göstermesi ve örnek olması dolayısıyla bir lider figürünü temsil etmektedir. Film boyunca Ferman'ın işi dışındaki zamanını evinde hasta eşiyle geçirdiği görülmektedir. Böbrek hastası olan eşi, organ nakli için başvuruda bulunmuş, sıra kendisine geldiğinde ise kendi hakkını daha genç bir kadına devretmiştir. $\mathrm{Bu}$ genç kadın ise her gün Ferman'ın eşinin bakımına yardımcı olarak minnet borcunu göstermektedir.

İdris (Cem Yılmaz): İdris duygusal tepkileri ve cesareti ile teşkilatta "Deli" lakabıyla anılmaktadır. Karadenizli İdris yine kendi memleketinden Asiye ile bir zamanlar çok severek evlenmiş, bu evlilikten çiftin iki çocukları olmuş ancak çift İdris'in şüpheciliği yüzünden ayrılmıştır. İki çocuğu ve annesi ile yaşayan İdris Asiye ile tekrar bir araya gelmeyi istemektedir ancak bu çabalarında kontrolünü hep kaybeder ve şiddete eğilimi eski karısı ile aralarındaki yakınlaşmaları boşa çıkartır. İdris, Ferman ile bir baba oğul ilişkisi kurmuştur ve filmde bunu yer yer hatırlatır.

Hasan (Okan Yalabık): “Çömez” Hasan, adı üstünde ekibe yeni katılmıştır. Aslında antropoloji mezunu olan Hasan, kan ve ceset görmeye hiç alışık değildir ve üzerine sindiğini düşündüğü kan kokusu ile başa çıkmaya çalışır. Cinayet masasındaki kariyerinin alternatifi ise, ne tesadüftür ki, et lokantaları zinciri sahibi olan müstakbel kayınbabasının lokantalarından birinin başına geçmektir.

Battal Çolakzade (Çetin Tekindor): Pamuk ve ailesinin uzun yıllardır yanında çalıştıkları ve "velinimetimiz" diye adlandırdıkları Battal Çolakzade, Türkiye'nin önde gelen iş 
adamlarından biridir. Filmde Battal'ın ailesinden ölümcül bir hastalıkla yatan kızı Ceylan ve hep sakin hareket eden karısı Hilal de görünmektedir. Battal film boyunca kendi babasının sözlerine atıfta bulunarak hayatın bir av ve avcı ilişkisi olduğuna dair anektodlar sunar.

Müslüm (Mustafa Avkıran): Müslüm, iki oğlu Abbas ve Vakkas, kızı Pamuk ve karısı Hatun ile birlikte Battal Çolakzade'nin yanında çalışmaktadır. Hatun'un aksine Müslüm Pamuk'a kızgındır, onun kocasını terk ederek namuslarını kirlettiğini düşünmektedir ve ölümüne üzülmediğini belirtmektedir.

Bu aralık, Asiye ile arasını düzeltme konusunda mesafe aldığını düşünen İdris, tekrardan kesin bir ret aldığında karısıyla yemek yediği restoranı dağıtır ve bu geri dönüşü olmayan bir şekilde Asiye'yi kaybettiği anlamına gelmektedir. Asiye'nin kaybı İdris için yokluktur ve bu yokluktan aldığ 1 cesaretle bir gece alkol de alarak Çolakzade'nin evine gizlice girer ve bu cesareti hayatına mal olur.

\subsection{Gönül Yarası}

\subsubsection{Film Özeti}

Nazım (Şener Şen), kendini öğretmenlik mesleğine adamış ve Anadolu'nun ücra köylerinde mesleğini sürdürmüştür. Emekli olduktan sonra İstanbul'a döner ve mesleği ve öğrencileri için yaptığı fedakarlıkların ailesini ihmal etmesine neden olduğunu, onu çocuklarından kopardığını ve yalnızlaştırdığını fark eder. Nazım yakın arkadaşı Takoz'un bulduğu bir evde yaşamaya ve onun taksisinde geceleri şoförlük yapmaya başlar. Şoförlük yaptığı gecelerden birinde Dünya (Meltem Cumbul) ile tanışır. Dünya, küçük yaşta hayatın zorluklarıyla karşılaşmış, sokaklarda yaşamış ve pavyonda çalışmış bir kadındır. Hayatın zorlukları arasında bir tutunma dalı olarak gördüğü ve etkilendiği Halil ile evlenip bir çocuk dünyaya getirir lakin Halil'in şiddetinden kaçarak İstanbul'a gelir ve bir pavyonda şarkı söylemeye başlar. Dünya'nın başı şiddete eğilimli Halil ile de derttedir. Bir gün, Nazım'ın taksisine bindiğinde her ikisinin de hayatı değişir. Nazım, Dünya'yı her gün işe götürüp getirmeye başlar. Halil'in pavyonu basmasının ardından Nazım Dünya'yı ve kızı Melek'i yanına alarak yaşamaya başlar. Öğretmen Nazım ile taban tabana zıt bir karakter olan Dünya'nın eski kocası gizli ve adaletsiz bir rekabete tutuşurlar. Halil ile öğretmen Nazım'ın ilişkileri oldukça muğlaktır. Öğretmen emeklisi geçkin bir adamla, tutkun bir genç adamın dalgalı bir ilişkisidir söz konusu olan. Halil Nazım'a ve Nazım'ın çevresindeki erkeklere pişman olduğunu anlatır ve Dünya'yı ona geri dönmesi için ikna eder; kızlarını da alarak memleketlerine geri dönerler. Ancak Halil'in verdiği sözü tutmaması üzerine Dünya Nazım’ı yaşadıkları yere çağırır. Dünya'yı ve kızı Melek'i yanında götürmeye ve eskisi gibi yaşamaya niyetlenen Nazım İstanbul'a sadece Melek'i götürür zira son kez konuşmak isteyen Halil önce Dünya'yı sonra kendisini silahla öldürür. 


\subsubsection{Filmdeki Karakterler}

Nazım: Nazım (Şener Şen), hayatı boyunca kendini öğretmenlik mesleğine adamış ve Anadolu'nun ücra köylerinde mesleğini sürdürmüştür. Emekli olduktan sonra İstanbul'a döner ve mesleği ve öğrencilerine karşı yaptığı fedakarlıkların ailesini ihmal etmesine neden olduğunu, onu çocuklarından kopardığını ve onu yalnızlaştırdığını fark eder. İstanbul'da tanıştığı Dünya ile kurduğu ilişki onun yeni hayatını belirleyecektir. Şiddetten uzak durur, şefkatli ve iyi yüreklidir.

Dünya: Küçük yaşta tecavüze uğradıktan sonra ailesi tarafından dışlanmış ve bir pavyonda çalışmaya başlamıştır. Hayatın zorlukları arasında bir tutunma dalı olarak gördüğü ve etkilendiği Halil ile evlenip bir çocuk dünyaya getirir lakin Halil'in şiddetinden kaçarak İstanbul'a gelir ve bir pavyonda şarkı söylemeye başlar. Dünya'nın başı şiddete eğilimli Halil ile de derttedir. Dünya tüm yaşadığg zorluklara rağmen hayat dolu ve neşeli bir mizaca sahiptir.

Halil: Karısı Dünya Halil'i gösterdiği şiddet yüzünden terk etmiştir. Karısının kendisine dönmesi için her şeyi yapan Halil Dünya'nın peşinden İstanbul'a gelir. "Erkekliği”" zedelenmiş, kaybolan iktidarını tekrar tesis edebilmek için her yolu denemekten geri durmaz.

Takoz: Nazım'ın yakın arkadaşı Takoz İstanbul'da yaşamakta ve taksicilik yapmaktadır. Nazım'ın İstanbul'da yeni bir hayat kurabilmesi için elinden geleni yapar. Eski bir kabadayıdır ve yaşlılıkla birlikte fiziksel gücünü yitirmiş olmak Takoz'a üzüntü vermektedir.

Mehmet: Kendisinin de bir oğlu olan Mehmet paraya önem veren bir kişi olarak çizilmiştir. Kız kardeşi gibi babasına kızgındır ancak ondan farklı olarak kızgınlığı evlatbaba ilişkilerinden ziyade babasının satmadığı evi ile ilgili meselelerde gün yüzüne çıkmaktadır.

\section{ERKEK ŞIDDETI}

Şiddet kavramı üzerine uzun yıllardır hem teorik alanda hem de disiplinlere özgü saha çalışmalarıyla çeşitli yaklaşımlar geliştirilmiş ve farklı tanımlar yapılmıştır. Kavrama en genel anlamda baktığımızda ise Dünya Sağlık Örgütü’nün tanımına göre şiddetin "bireyin kendisine, başkasına, belirli bir topluluk veya gruba yönelik yaralama, ölüm, fiziksel zarar, bazı gelişim bozuklukları veya yoksunluk ile sonuçlanabilen, tehdit ya da fiziksel zor kullanma" anlamına geldiği görülmektedir (Dahlberg ve Krug, 2002:5). O halde şiddetin en temelde bir iktidar kurma aracı olduğunu söyleyebiliriz. İktidar da en kaba haliyle şiddet mağdurunu kaynaklardan yoksun bırakma, potansiyelini kullanamamayı sağlama şeklinde gerçekleşmektedir. Aynı zamanda şiddet ile güç arasında ters yönlü bir ilişki olduğu da söylenebilir zira aslında şiddet gücün bittiği, kapasitenin gücün devamını sağlayamadığı alanlarda ortaya çıkar (Arendt, 1970). Şiddet, aynı zamanda cinsiyet rollerini farklı yollardan şekillendiren bir etkiye ve cinsiyet temelli şiddetin kadınlar ve LGBT-İ bireylerin Türkiye'de toplumsal, ekonomik ve siyasal hayattan dışlandığg en büyük mekanizmalardan bir tanesini oluşturmaktadır (Altınay ve Arat, 2009). Toplumsal cinsiyet ilişkileri perspektifinden bakıldığında şiddetin 
erkeklerin, kadınlar, diğer erkekler ve doğa üzerindeki iktidarlarını kurma, kaybettikleri zaman ise yeniden kazanma çabalarının önemli bir aracı olduğu göze çarpmaktadır. Ertürk'ün de işaret ettiği gibi kadına şiddet, "tarih boyunca normalleşen ve ataerlik düzen içinde kurumsallaşan kadın ve erkek arasındaki ilk ve temel iş bölümünü idame ettirmede kullanılan olağan bir araç olagelmiştir" (2015:32).

Literatüre baktığımızda erkek şiddeti yerine erkeklerin şiddeti demenin hem feminist mücadele açısından hem de bahsettiğimiz şiddeti daha iyi anlamak açısından önemli olduğu görülmektedir. İlk olarak Hearn'in de işaret ettiği gibi "erkeklerin şiddetleri" kavramıyla şiddet ile erkeklik arasındaki özcü bağlantı çabalarını ortadan kaldırmak yönünde bir adım atılmış olmakta ve şiddetin erkek biyolojisinin kaçınılmaz bir sonucu olduğuna ilişkin biyolojik ve sosyobiyolojik açıklamalara karşı çıkılmaktadır (akt. Bozok, 2015). Zira erkekler aslında şiddetler ile kaçınılmaz ve ayrılamaz bir ilişki içinde olmak zorunda değiller ve (pro)feminist erkeklik siyasalarının da sık sık altını çizdiği üzere "başka türlü erkeklikler mümkün". Bununla birlikte erkeklerin şiddetininsadece kadınlara değil, kadınlara, queer bireylere diğer erkeklere de yöneldiğini ve erkek egemenliğinin önemli bir bileşeni olduğunu vurgulamakta fayda var (Kaufman 2001, akt. Bozok 2015) . Farklı erkeklik biçimleri farklı erkek şiddetleri, ya da erkeklerin şiddet ile kurduğu farklı ilişki biçimlerini de beraberinde getirmektedir. Erkeklik ile şiddet arasındaki organik ilişki, erkeklik biçimlerinin şiddetle olan ilişki üzerinden anlaşılmasına ve kategorize edilebilmesine imkan sağlamaktadır. Bu makale çerçevesinde incelenen filmlerdeki erkek karakterleri de şiddetle ilişkileri bağlamında analiz edilecek ve sınıflandırılacaktır.

\section{1. Şiddetle Sevenler}

Erkekler kadınlara istedikleri şeyleri yaptırmanın bir yolu olarak şiddet yoluna başvurmaktadırlar. Bu şiddet kadın cinayetlerini de içeriyor. Şiddetin yaptırım gücü olarak iktidar ilişkileriyle arasındaki organik bağ elbette ki kaçınılmazdır. Arendt (2012) tam bu noktada şiddetin iktidarın tehlikeye girdiği anlarda ortaya çıktığını ileri sürmektedir. Erkek şiddeti de erkeklerin iktidarlarını kaybettiklerini, bir güç simgesi olarak "erkekliklerini” yitirdiklerini düşündükleri anlarda ortaya çıkar. Gönül Yarası ve Av Filmlerinin hareketli karakterleri Halil ve İdris eski eşlerini kendilerine döndürmek için türlü yolları denemekte, şiddetsizlik sözü verip yine şiddete başvurmakta, kadınları kaybettiklerini anladıkları noktada ise tek bildikleri çözüm, şiddete yönelmektedirler.

Turgul filmlerinde bu şiddetin sevgiyle iç içe resmedildiğini görüyoruz. Halil, Dünya'yı öldürmeden önce ondan gitmemesini ister ve son bir türkü söylemesini ister. İdris, tam Asiye'yi öldürecekken elektrikler kesilir ve karanlıktan korkan Asiye'nin İdris'e sığınmasıyla bir yakınlaşma olur. Asiye, muhtemel katiliyle romantik bir gece geçirir. Asit, ona kaçan sevgilisi Pamuk'u döver. Battal'ın sevgisinin şiddet ile olan bağı ise bu üç erkekten farklı yansımaktadır. Kızı Ceylan'a olan sevgisi Ceylan'ı hastalıktan kurtaracak her şeyi yapmasına, herkese zarar verebilmesine yol açmaktadır. Zira bu yolda Pamuk'un böbreğini gasp ettirmiş, Asit, Ömer'i Vakkas'a vurdurmuş ve dolaylı olarak İdris'in ölümüne neden olmuş, en sonunda da ölümü yine kendi elinden olmuştur. Battal'ın uyguladığı şiddetin diğer şiddetle sevenlerden iki farkı vardır; birincisi Battal'ın uyguladığı şiddet, sevdiği kişiye yönelmemektedir. İkincisi ise kendisi doğrudan şiddet uygulamaktansa elindeki gücü kullanarak başkalarına bu şiddeti uygulatmaktadır. 
"Bir aile sahibi" olmak ve onu geçindirmeyi başarmak bizatihi kendine ait bir "iktidar alanı"na sahip olmak anlamına gelmekte ve babalık bu anlamda erkekliğin oluşmasında önem kazanmaktadır. Toplumsal cinsiyet üzerine önemli çalışmaları bulunan Serpil Sancar (2009: 120), Türkiye'deki erkeklerin erkeklik deneyimlerini incelediği ve hangi erkeklerin egemen olduğunu anlamaya çalıştı̆̆ “İmkansız İktidar” isimli çalışmasında babalık kavramından "erkek olmanın anlaşılması en zor hallerinden biri" olarak bahseder. Babalığın bu karmaşıklığı; anne ile çocuk arasındaki ilişkinin tanımlanmasındaki doğrudan bağlantının yokluğundan kaynaklanmaktadır. Babalık, kadınların "doğurarak anne olmak" bağlantısı kadar somut bir kavramayı olanaklı kılmaz, doğrudan biyoloji yoluyla açık ve belirgin bir ilişki olarak kurulamaz ve sosyal ve/veya siyasal birtakım ilişkileri gerektirmektedir (Sancar, 2009). Daha açık ifade edersek babalık ancak toplumsal ve siyasal uzantılarla birlikte düşünüldüğünde kurulabilen bir roldür. $\mathrm{Bu}$ uzantılar hukuki ve kültürel boyutlar içerir ve babanın çocuklarını ve bu çocukların annesini/annelerini geçindirme gücüne sahip olması gerektiği varsayımına dayanır. $\mathrm{Bu}$ noktada erkekler babalık sorumluluğunu üstlendikleri ailelerini geçindirme kapasiteleri bakımından eşit değildir. Cinsiyet rollerinin uzantısıyla aile içinde çocukla kurulan bağda ebeveynler farklı sorumluluklar alırlar ve en genel anlamıyla babaya düşen toplumla bağın kurulmasıdır (Parsons, 1955).

Başka bir deyişle baba; aile, özellikle çocuk söz konusu olduğunda devletin ve piyasanın muhatabı olan kişidir ve bu bir yetkiyi de ifade etmektedir. Bir yetki sahibi olarak aile reisi babanın çocuklar ve çocukların annesi üzerinde hakkı vardır ve babalık yasal zeminde ailedeki çocuklara bakmakla ve eğitmekle yükümlü vatandaş, yani "velayet ve vesayet sahibi" erkeği ifade etmektedir (Sancar, 2009). Toplumsal cinsiyet rejiminin kaçınılmaz bir getirisi olarak toplumsal hayatın çeşitli alanlarında farklı roller edinen kadın ve erkeğin ebeveynlikte de farklı sorumluluklar aldığı ve birbirinden farklı algılandığını söylemek bu noktada yanlış olmayacaktır. Dündar vd.'nin (2011) anne ve babanın akıllara getirdiği sözcüklerin incelenmesiyle hazırladıkları çalışma ise babalığın kamusal alanla çocuk arasında bağ oluşturma rolünü daha net ortaya koymaktadır. Bahsi geçen çalışmada anne sözcüğünün sevgi, fedakârlık, yemek ve şefkat gibi sözcüklerle; baba sözcügünün ise para, saygı, ev geçindirme ve reis gibi sözcüklerle daha çok ilişkilendirildiği ortaya konulmuştur.

Biyolojik bağlantıların ötesinde toplumsal ve hukuksal ilişkilerle beraber babalık bir anlamda kazanılan bir statüdür. Erkekler, çeşitli yollarla erkekliklerini ispatlayarak baba olurlar. Baba olunabilmesi için erkeklerin önce cinsel anlamda kendilerini ispat etmeleri gerekir. Daha sonra ise evin bakıcısı-koruyucusu olduğunu ispat edebileceği beceriler geliştirebilmeli; evle ilgili ekonomik, hukuki, siyasal tüm kararları alan patron ve devlet adamı olabilmelidir (Selek 2008: 22-23). Babalık rolünün annelikte olduğu gibi sadece biyolojik bir süreç ile doğrudan ilişkilendirilememesi; hukuki, toplumsal ve kültürel yansımaları babalığın kültürel ve özellikle de maddi aktarım ile yakından ilgili olmasını da beraberinde getirmektedir. İdris'in ve Halil'in parçalanmış aileleri onların iktidar alanlarına da zarar vermekte bu iktidar kaybı onları şiddete daha çok itmektedir.

Dünya'nın türkü söylerken Nazım'a sevgi dolu bakışını gören Halil, Dünya’nın üzerinde hiçbir kontrolünün kalmadığını ve artık onu sonsuza kadar kaybettiğini anlamış ve tetiğe basmıştır. İdris de benzer bir şekilde kendisine dönmeye razı edemediği eski karısı 
Asiye'yi patronu ile yakın ilişki içinde görmüş ve bu durumun kendisine yaşattığı iktidar kaybı karşısında silahına sarılıp Asiye'nin evinin yolunu tutmuştur.

Gönül Yarası filminde Halil, Dünya'ya kamusal alanda şiddet uygulamaktadır. Bir erkeğin bir kadına kamusal alanda uyguladığı şiddet, o kadını kendi mülkiyeti olarak görmesine işaret etmektedir (Yaşartürk 2010: 24). Filmde ara ara Dünya'nın Halil'den sokakta, çalıştığı barda şiddet görüyor olması Halil'in Dünya'ya yaklaşım biçimini ortaya sermekte, boşanmış olmanın bile onu kendi mülkiyetinde görmesine engel olmadığını, Dünya'nın herhangi bir erkekle herhangi bir yakınlık kurmasını kendi alanına bir saldırı olarak göreceğini anlatmaktadır. Yine aynı filmde yönetmen bize Halil'in şiddetinden daha çok o şiddetin sonuçlarını gösterir (Yaşartürk 2010:199). Melek babasının şiddeti yüzünden lal olmuştur lakin izleyici onu lal yapan şiddeti göremez. Nazım ile Dünya otogarda buluştuğunda Dünya'nın yüzünde yara izleri vardır ancak izleyici olarak bu yara izlerinin nasıl olduğunu görmezken Takoz'a ve kahvedeki diğer erkeklere aslında Dünya'yı ne kadar sevdiğini, onun için ailesinden koptuğunu, işini kaybettiğini anlattığg sahneleri izleriz. Bu tezat, izleyicinin Halil ile empati kurmasını ve şiddetini haklılaştırmasını da içermektedir. Halil'in kahvehanedeki erkeklerle paylaştığı geçmişi aslında erkek dayanışmasına bir çağrıdır. $O$ güne kadar Halil'in Dünya'ya şiddet göstermesine kızan Takoz ve kahvehanedeki diğer erkekler Halil'in haline de üzülürler ve Halil'in Dünya ile kendilerini barıştırma taleplerini kabul ederler. Halil'in şiddeti hoş görülmüş ve erkek şiddetinin gerekçeleri üzerinden bir erkek yoldaşlığı kurumuştur. Erkeklerin bu tür ihlallerinin üstesinden yine erkek dayanışması ile gelmek mevcut erkeklik algısını beslemektedir (Barutçu 2013:152). Şiddet gösteren erkeğin diğer erkeklerden dayanışma talep etmesi ve bu talebin olumlu cevap ile sonuçlanması, erkekliğin şiddet ile organik bağından kaynaklanmaktadır. Zira Cockburn (2001)'nün de belirttiği üzere dünyadaki birçok kültürde -Türkiye'de de olduğu gibi- erkeklik kavga pratiği üzerine kuruludur, gerçek erkek olmak demek bir anlamda da kavgaya, yani ölmeye ve de öldürmeye hazır olmak demektir.

\section{2. İdealist Eksik Babalar}

İki filmin de ana karakteri Ferman ve Nazım'ın pek çok ortak özelliği bulunmaktadır. İlk olarak ikisi de filmlerde ele avuca sığmayan, şiddete eğilimli genç erkekleri dizginlemeye çalışmaktadır. Av Mevsimi'nde İdris, Gönül Yarası'nda ise Halil onların dış dünyayla uyum sağlamasını sağlayacak bir otorite figürüne ihtiyaç duyarlar. Nazım'dan Dünya'yla ilişkisini düzeltmesine yardımcı olmasını isteyen Halil ve özellikle eski karısıyla olan sorunları konusunda Ferman'a akıl danışan İdris, kurtarıcı baba figürüne yönelik bir arayışı simgelemektedir (Yüksel 2013:290).

Ferman da Nazım da filmin "kötü" karakteri ile de bir rekabet içinde yer almaktadır. Ferman ile Battal arasında amansız bir rekabet vardır. İkisi de avcıdır. Nazım, Halil için akıl soracağı bir baba figürüdür ve Dünya'nın Halil'e dönmesine yardımcı olur. Ancak bu Halil ile aralarındaki rekabete engel değildir. İkisi de Dünya'ya aşıktır. Bir anlamda ikisi de dünyanın peşinden koşmaktadır (Çatalbaş 2012). Bir zamanlar Halil'in yakışıklılığına vurulan Dünya, artık bunun bir önemi olmadığının farkına varmış ve Nazım'ın merhametini istemektedir. Dünya'yı ölüme götüren de aslında iki erkek arasındaki bu rekabet olur. Halil'in Dünya'nın kaçmasını engellemeye yanında silah ile 
gelmesi potansiyel bir katle işaret etmekte, ancak tetiği Dünya'nın türkü söylerken Nazım'a sevgi dolu bakışlarını yakaladığı an çekmesi bu rekabet ile cinayet arasındaki ilişkiyi gösterir. Nazım ile Halil arasında yine Dünya ve kızı Melek üzerinden gelişen bir erkek dostluğu da vardır. İtişme kakışma esnasında Nazım fenalaşınca Halil'in onu hemen sırtlamaya çalışması Nazım'ın ise onu durdurması ikisinin de erkeklik biçimini ve birbirleriyle kurdukları ilişkiyi özetler niteliktedir. Halil tez canlı, fiziksel gücüne güvenmekte, Nazım sakinliğe davet etmekte; Halil kavga anında bile Nazım'a yardım etmek istemektedir. Nazım, Halil'e nasıl davranması gerektiğini öğretir, karısını dövdüğü için "sen nasıl erkeksin?" diye sorar. Halil'in kendini vurmadan önceki son sözü "affet abi, sözünü tutamadım" olur.

$\mathrm{Bu}$ iki erkeğin de aile hayatı sıkıntılarla doludur. İkisi de idealisttir, işlerine yürekten bağlıdırlar. Peşlerinden gittikleri fikirler vardır. Zaten onları çevreleri için değerli kılan tam da bu özellikleridir. Öte yandan bu idealist erkeklerin babalıkları "eksiktir". Şöyle ki Ferman ve karısının çocukları olmamış, Nazım'dan çocukları şikâyet etmektedir zira onlarla hiç ilgilenmemiş, sevgisi ilgisini okuluna, okulundaki çocuklara vermiştir. İstanbul'a gelir gelmez soluğu can dostu Takoz'un yanında almış, çocukları bu duruma çok içerlemiştir. Nazım, çocuklarını ihmal ettiğini sonradan fark eder, ama elinden bir şey gelmez, ama bir daha dünyaya gelse yine aynı şeyleri yapacağını belirterek hem "eksik babalığını" hem "idealistliğini" teslim eder. Ferman ise hiç baba olmamış, çocuklarının olmayışının hüznünü filmde yer yer dile getirmiştir. İdris'e babalık etmekte, İdris onu babasının yerine koymaktadır. Ferman bir baba olarak çocuğunu koruyamaz, İdris bu av mevsiminde kurşunların hedefi olur ve Battal'ın korumaları tarafından öldürülür.

Ferman ve Nazım, sakinliklerinin yanı sıra genellikle kadınlara atfedilen bakım emeğini çevrelerine yansıtmalarıyla gösterilmektedirler. Gönül Yarası'nda Nazım İstanbul'da taşındığı evde cam siler, ev işi yapar; Dünya ve Halil öldükten sonra Melek'e bakar, öğretmenlik yıllarında öğrencilerine emek harcar. Ferman evde iş yaparken, bir çocukla ilgilenirken görünmez lakin hasta karısıyla ilgilenir, onunla çok insani bir sevgi ilişkisi kurduğu gösterilir. Şiddet ve erkeklikle olan ilişkinin dolayımsız gözlemlendiği İdris ve Halil için bir otorite figürü olan Ferman ve Nazım bu anlamda bu anlamda feminen özellikler de göstermektedirler.

\subsection{Beyaz Erkekler}

Gönül Yarası ve Av Mevsimi Filmleri'nde göze çarpan diğer bir erkek tipi de bu çalışma kapsamında beyaz erkekler olarak adlandıracağımız kentli, eğitimli, orta sınıf, şiddetten uzak duran erkeklerdir. Bu erkekler iyi eğitim almış ve/veya beyaz yaka ve prestijli mesleklere sahip, entelektüellerdir. Şiddet göstermezler ama şiddet mağduru olabilirler. Av Mevsimi'nde ismi anılmayan Asiye'nin patronunun göründüğü üç sahneden birinden arabasından inmiş, diğerinde de arabasına binmek için otoparkta yürümektedir. Düzenli bir işi ve arabası olan bir erkektir, daha da ötesinde bu haliyle Asiye'nin karşısında kendisinden daha çok şansı olması İdris'i öfkelendirir. İdris'in fiziksel saldırısına hedef olmuş, ama karşılık vermemiş, İdris'in ona gösterdiği şiddet Asiye'yi İdris'ten daha da uzaklaştırmıştır. Av Mevsimi'ndeki Halil karakteri de bu erkek kategorisinde yer almaktadır. Halil Ferman'ın ekibine yeni katılmıştır. Kitap okuyan, antropoloji yüksek 
lisansı yapan ve “entel” olması gerekçesiyle İdris'in müstehzi tavırlarına maruz kalır. Halil, yeni başladığı mesleğine bir türlü 1sınamaz. Polisliğin şiddet ve kanla olan doğrudan payı onu bir çıkmaza sokmuştur. Gönül Yarası'nda Nazım'ın kızı Piraye evlenmek istediği Tolga'yı babası ve abisi ile tanıştırmak üzere Ferman'ın evine getirir. Tolga yüksek eğitim görmüş bir ailenin oğludur, Amerika'da okumuş ve banka müdürü olmuştur. Kendinden bahsederken Piraye'nin abisi Mehmet'in ve Nazım'ın takdiri yüzlerinden okunmaktadır.

Yavuz Turgul'un filmlerinde beyaz erkekler olarak niteleyebileceğimiz bu karakterlerin üçü de açık tenli ve sarışın oyuncular tarafından canlandırılmış, kıyafet seçimleri de diğer ouyunculara göre daha batıl1-kentli bir tarzda olmuştur. Bu erkekler, eğitim, kariyer, zevk, entelektüel birikim gibi konularda diğer erkeklerin hem takdirini kazanmakta ve kendilerine gipta edilmekte hem de diğer erkeklerin şiddetine maruz kalmakta ve alay konusu olabilmektedir. $\mathrm{Bu}$ erkeklerin sahip oldukları şeyler diğer erkekleri öfkelendirebilmektedir. Öte yandan bu erkekler diğerleri gibi erkeklere özel mekanlarda gösterilmemekte, erkek dostluğu kuramamaktadırlar. Hem oyun dışı hem de oyunda güçlüdürler.

\section{SONUÇ}

Türk sinemasının 90'lar sonrasında hızla gelişen popüler hattını belirleyen Yavuz Turgul'un iki filminden yola çıkılarak erkeklik tipleri incelendiğinde, uzun süredir tartışıldığı gibi erkeklik ve şiddet arasında yakın ilişki de göze çarpmaktadır. Şiddet, erkek iktidarının en önemli kurucu unsurlarından bir tanesini oluşturmakta, ama uygulayan dahil failin çevresindeki kadın-erkek neredeyse herkese zarar vermektedir. Örneğin İdris'in eski karısı üzerindeki kontrolünü yitiriyor olması, bir aile babası olamaması onu iktidarını tazelemek için şiddete başvurmaya iter. Asiye'nin patronunu döver, cinayet masasındaki ekibe yeni katılan Halil'e fiziksel bir şiddet uygulamasa da onu aşağılamaktan geri durmaz. Kendi çocukları da bu şiddetin mağdurları arasında yerlerini alırlar. Çocuklarını da Asiye'yi istemediği şeyleri yapmaya zorlamanın bir aracı olarak kullanır. İdris ve Halil çocuklarını da şiddetle severler ve kadınlara duydukları şiddetli sevginin de bir parçası haline getirirler. Çocukları onlar için Asiye ve Dünya'yı kendilerine geri döndürmeye ikna etme mücadelesinin en önemli araçları haline gelir. İdris çocukları Asiye'ye göstermemekle tehdit eder, Halil kızı Melek'i annesinde kaçırır ve Melek'in babasının annesine uyguladığ süreliğine kaybettiğini izleriz.

Erkeklerin şiddeti erkeklere de yönelmektedir. Asiye'nin patron İdris’ten Dayak yemekte, Halil İdris'in zorlamalarına maruz kalmaktadır. Asiye'nin patronu beyaz yaka bir çalışandır; modaya uygun giyinen, traşlı, araba sahibi, filmde gösterildiği kadarıyla literatürdeki hegemonic erkeklik tipine en yakın karakteri sergilemektedir. Av Mevsimi'ndeki Halil de antroploji yüksek lisansı yapmakta, polisliğin şiddetle olan bağına alışamamakta bu yönü ve entellektüelliği yüzünden İdris tarafından dolaylı olarak erkekliği sorgulanmaktadır. Bu açılardan benzer özellikler gösteren Halil ve Asiye'nin patronu erkeklerin şiddetinin mağdurudur. Biraz daha yakından bakıldığında Takoz'un yaşadığ iç çelişkilerin de kendi erkekliğinin şiddete temas noktalarından kaynaklandığ1 ve onun da erkekliği şiddetle kurduğu ilişkinin mağduru olduğunu söyleyebiliriz. 
Nazım'ın “Bu alemde kral senmişsin Takoz!” ifadesinin üzerine Takoz şöyle bir cevap verir, "Ne krall, o bir zamanlardl, şimdi sermayeden yiyoruz. Ödüm kopuyor biri posta koyacak da kavgaya gireceğim diye. Ya dayak yersek ne olacak, ya kurt kocadı köpeklerin maskarası oldu dedirtirsem? Karizma çizildi mi Takoz efsanesi bitti demektir. Onun için beladan uzak duruyorum. Eskiden kavga görünce dayanamaz içine dalardım, şimdi başımı çevirip geçip gidiyorum. Bu da ă̆ırıma gidiyor aslında." Yaşlanma ve fiziksel gücün düşüşü, Takoz’un şiddet ile bağını zayıflatmış, bu durum ise Takoz için içinden çıkılması zor bir durum yaratmıştır.

Av Mevsimi'nde öldürülmeden önce Pamuk'a şiddet uyguladığı bilinen Asit Ömer de erkeklerin şiddetini besleyen ataerkil değerlerin bir sonucu olarak Vakkas tarafindan öldürülür. Vakkas kızkardeşi Asit'e kaçtığı için emniyet müdürlüğünde onu öldürür, namusunu temizler. Filmde açıktan gösterilmese de Battal'ın Vakkas'ı böyle bir cinayete azmettirdiği açıktır. Asit aslında olayın iç yüzünü bildiği için öldürülmüş, ancak cinsiyet rejiminde erkeklerden beklenen roller gereği Vakkas böyle bir cinayeti işleyeme ikna edilebilmişti. Sistemin erkeklerden beklentilerini Battal'ın kendi amaçları doğrultusunda kullanmasıyla Asit maktül, Vakkas katil olmuştur.

Bu makale kapsamında incelenen iki filmde açık olduğu ve teorik tartışmalarda da sıklıkla belirtildiği gibi tek ve sabit bir erkelikten bahsetmek imkansızdır. Erkekler içinde bulundukları sınıfsal, coğrafi, iktisadi, kültürel ve etnik konumlara göre, yaş, medeni durum, aile yapısına göre farklı özelliklerle erkekliklerini birlikte deneyimlerler. Bunun da ötesinde erkekliğe verilen anlam zaman içinde de değişmektedir. Tartışması bu makalenin ötesine geçecek kimi sebeplerle kadınlar gittikçe daha artan oranlarda iş piyasasına dahil olmuş, kamusal hayatta, siyasette, sivil toplumda ve toplumsal hareketlerde yer almaya başlamıştır. Kadınların sadece hane bütçesine katkı yapmakla kalmayıp evi de geçindiriyor olması, tek ebeveynli aile yapısının yaygınlaşması ve diğer pek çok neden annelik ve babalık rolünü de dönüşüme zorlamıştır. Bu dönüşüm erkekliğin de farklı biçimlerini beraberinde getirmiş, dönüşümünü sağlamıştır. Şiddet, hala erkekliğin en büyük dayanak noktası ve iktidarı zora düşen erkeklerin başvurduğu önemli bir araçtır. Ancak farklı erkeklik biçimlerinin imkânı ve toplumsal şartların zorlayıcı etkisiyle cinsiyet rollerinin değişimi erkeklik ve şiddet arasındaki bağın zayıflamasını beraberinde getirebilir.

\section{NOTLAR:}

${ }^{1}$ Yüksel (2013), Yavuz Turgul filmlerini tarihsel toplumsal bağlam içinde sosyolojik bir okumayı olanaklı kılan diğer iki ana temanın "toplumsal değişim" ve "Doğu-Batı ikiliği" olduğunu söylemektedir.

\section{KAYNAKÇA}

Abisel, N. (2000). Yeşilçam Filmlerinde Kadının Temsilinde Kadına Yönelik Şiddet. Nur Betül Çelik (Ed.), Televizyon, Kadın ve Şiddet içinde (s.173-212). Ankara: Dünya Kitle İletişimi Araştırma Vakfi KIV Yayınları.

Abisel, N. (2005). Türk Sineması Üzerine Yazılar. Ankara: Phoenix Yayınları. 
Altinay, A.G., \& Arat, Y. (2009). Violence Against Women in Turkey, A Nationwide Survey. İstanbul: Punto Publishing Solutions.

Arendt, H. (2012). Şiddet Üzerine. İstanbul: İletişim Yayınları.

Badinder, E. (2011). Kadınlık mı Annelik mi?. İstanbul: İletişim Yayınları.

Barrett, F.J. (2005). The Organizational Construction of Hegemonic Masculinity: The Case of the US Navy. In Stephen M. Whitehead \& Frank J. Barett (Ed.), The Masculinities Reader. Malden: University of California Pres.

Barutçu, A. (2013). Türkiye'de Erkeklik İnşasının Bedensel ve Toplumsal Aşamaları. Yüksek Lisans Tezi. Ankara Üniversitesi.

Bazin, A (1995). Çă̆daş Sinemanın Sorunları. Nijat Özön (Çev.). Ankara: Bilgi Yayınevi.

Bozok, M. (2011). Soru ve Cevaplarla Erkeklikler. İstanbul: SOGEP.

Bozok, M. (2015). Erkeklerin Şiddeti, Şiddetlerin Erkekleri. [Erişim: 08.08.2016], http://viraverita.org/yazilar/erkeklerin-siddetleri-siddetlerin-erkekleri

Butler, J. (2008) Cinsiyet Belası. Başak Ertür (Çev.). İstanbul: Metis Yayınları.

Chandler, D. (2009). Marxist Media Theory. [Erişim: 28.10.2009], http://www.aber.ac.uk/media/Documents/marxism/marxism10.html

Cockburn, C. (2004). Mesafeyi Aşmak Barış Mücadelesinde Kadınlar. İstanbul: İletişim Yayınlar1.

Connell, R.W. (1987). Gender and Power: Society, the Person and Sexual Politics. Oxford: Blackwell Publishers Ltd.

Çatalbaş, A.Ü. (2012). Yavuz Turgul Sinemasının Türk Modernleşmesindeki Yeri. Doktora Tezi. Konya: Selçuk Üniversitesi.

Dönmez-Colin, G. (2013). The Routledge Dictionary of Turkish Cinema. New York: Routledge.

Dündar, Ö. Z., Durugönül, E., \& Arıkan, A. (2011). "Anne" ve "Baba" Sözcüklerine Yüklenilen Anlamların Bir İncelemesi. Contemporary Online Language Education Journal, 1(2), 25-34.

Erdogan, N. (2002). Mute Bodies, Disembodied Voices: Notes on Sound in Turkish Popular Cinema. Screen, 43(3), 233-249.

Erdoğan, İ. (2011). Medyada Hegemonik Erkek(lik) ve Temsil. İstanbul: Kalkedon Yayınları.

Ertürk, Y. (2015). Sınır Tanımayan Şiddet: Paradigma, Politika ve Pratikteki Yönleriyle Kadına Şiddet Olgusu. İstanbul: Metis Yayınları.

Güçlü, Ö. (2010). Silent Representations of Women in the New Cinema of Turkey. Sinecine, 1(2), 71-85. 
Kılınç, B. (2008). Yabancılaşmış Karakterler ve Politik Eleştiri: Yavuz Turgul Sinemasından 'Muhsin Bey' Örneği. Selçuk Üniversitesi İletişim Fakültesi Akademik Dergisi, 5(3), 220-235.

Kimmel, M. S., Hearn, J., \& Connell, R. W. (Eds.). (2004). Handbook of Studies on Men \& Masculinities. California: Sage Publications.

Kimmel, Michael S., Jeff Hearn, and Robert W. Connell, eds. Handbook of studies on men and masculinities. Sage Publications, 2004.

Özarslan, O. (2016). Hovarda Alemi, Taşrada Eğlence ve Erkeklik. İstanbul: İletişim Yayınlar1.

Özbay, C. (2013). Türkiye'de Hegemonik Erkekliği Aramak. Doğu Batı, 63, 185-204.

Parsons, T. (1955), Family Structure and the Socialization of the Child. In T. Parsons and R. F. Bales (Ed.), Family, Socialization and Interaction Process. New York: New York: Free Press.

Sancar, S. (2009). Imkânsız İktidar. İstanbul: İletişim Yayınları.

Scognamillo, G. (2005). Türk Sinemasında Şener Şen. İstanbul: Kabalcı Yayınları.

Selek, P. (2008). Sürüne Sürüne Erkek Olmak. İstanbul: İletişim Yayınları.

Smelik, A. (2006). Feminist Sinema ve Film Teorisi-Ve Ayna Çatladı. İstanbul: Agora Kitaplığı.

Suner, A. (2005). Hayalet Ev: Yeni Türk Sinemasında Aidiyet, Kimlik ve Bellek. İstanbul: Metis Yayınları.

Şimşek, A.A., \& Öner, R.V. (2015). Türkiye'de Hegemonik Erkeklik: Medyada ve Hukukta İzler, Dönüşümler ve Olasılıklar. Global Media Journal TR Edition, 6(11), 447-477.

Taşçıyan, A. (2011). Sinema Yazarlarından Görüşler: Yavuz Turgul, Haz. Ala Sivas, Yavuz Turgul Sinemasını Keşfetmek, İstanbul: Kırmızı Kedi Yayıncılık.

Yaşartürk, G. (2010). Domestic Violence from the Point of View of Women Directors in Turkish Cinema. Fe Dergi: Feminist Eleştiri, 2(1), 33-42.

Yüksel, S.E. (2013). Yavuz Turgul Sinemasında Toplumsal Değişim ve Kriz Anlatısı. Selçuk Üniversitesi İletişim Fakültesi Akademik Dergisi, 8(1), 282-294. 